JURNAL ILMU KESEHATAN BHAKTI HUSADA:

HEALTH SCIENCES JOURNAL, VOL. 11 NO. 01, JUNI 2020

DOI: $10.34305 /$ jikbh.v11i1.154
Ciptaan disebarluaskan di bawah

Lisensi Creative Commons Atribusi-

NonKomersial-BerbagiSerupa 4.0 Internasional.

\title{
PERBANDINGAN KADAR HEMOGLOBIN PADA REMAJA PREMENARCHE DAN POSTMENARCHE DI DESA RAGAWACANA KECAMATAN KRAMATMULYA KABUPATEN KUNINGAN TAHUN 2018
}

\author{
Fera Riswidautami Herwandar, Evi Soviyati \\ STIKes Kuningan \\ fera@pintarword.com
}

\begin{abstract}
Abstrak
Anemia merupakan salah satu masalah kesehatan di seluruh dunia terutama negara berkembang. Anemia pada remaja putri sampai saat ini masih cukup tinggi. Di Indonesia terdapat $21,7 \%$ penduduk dengan kadar hemoglobin kurang dari batas normal. Remaja putri memiliki risiko sepuluh kali lebih besar untuk menderita anemia dibandingkan dengan remaja putra. Hal ini dikarenakan remaja putri mengalami menstruasi setiap bulannya. Tujuan penelitian ini adalah untuk mengetahui perbandingan kadar hemoglobin pada remaja premenarche dan postmenarche.
\end{abstract}

Metode yang digunakan dalam penelitian ini adalah analitik dengan rancangan case control. Teknik pengambilan sampel yaitu dengan purposive sampling. Teknik pengumpulan data menggunakan lembar observasi dan pemeriksaan hemoglobin dengan menggunakan hemoglobin meter. Uji hipotesis menggunakan uji t test independent.

Hasil penelitian dari 42 responden yang telah diobservasi didapat rata-rata kadar hemoglobin pada remaja premenarche adalah $12,9 \mathrm{gr} / \mathrm{dl}$. Sedangkan pada remaja postmenarche adalah 12,0 gr/dl. Hasil analitik didapatkan tidak terdapat perbedaan pada kadar hemoglobin premenarche dan postmenarche dengan nilai $\mathrm{p}$ value 0,087 .

Berdasarkan hasil penelitian, penulis dapat menyimpulkan bahwa menstruasi dapat mempengaruhi terhadap penurunan kadar hemoglobin secara signifikan.

Bagi Desa Ragawacana Kecamatan Kramatmulya Kabupaten Kuningan diharapkan dapat bekerja sama dengan Puskesmas atau tenaga kesehatan lainnya, untuk memberikan pendidikan kesehatan tentang gizi seimbang remaja, kesehatan reproduksi, serta dapat mendukung program pemerintah yang sudah ada yaitu pemberian asam folat dan tablet tambah darah.

Kata Kunci : Remaja, Kadar Hemoglobin, Anemia 
JURNAL ILMU KESEHATAN BHAKTI HUSADA:

HEALTH SCIENCES JOURNAL, VOL. 11 NO. 01, JUNI 2020

DOI: $10.34305 /$ jikbh.v11i1.154
Ciptaan disebarluaskan di bawah

Lisensi Creative Commons Atribusi-

NonKomersial-BerbagiSerupa 4.0 Internasional

\section{Pendahuluan}

Menurut Irawan, (2018) secara global, hampir 600 juta anak usia prasekolah dan usia sekolah menderita anemia. Anemia merupakan salah satu masalah kesehatan di seluruh dunia terutama negara berkembang, anemia banyak terjadi pada masyarakat terutama pada remaja dan ibu hamil. Anemia pada remaja putri sampai saat ini masih cukup tinggi. Gejala anemia yang timbul adalah seperti kehilangan selera makan, sulit fokus, penurunan sistem kekebalan tubuh dan gangguan perilaku atau orang awam lebih mengenal dengan Gejala 5L (lemah, letih, lesu, lelah, lunglai), wajah pucat dan kunang-kunang (Irawan, 2018).

Menurut Dharma \& Sudhana, (2013) masalah gizi adalah masalah kesehatan masyarakat yang potensial berkembang di Indonesia. Anemia adalah salah satu masalah gizi mikro yang cukup serius karena menimbulkan berbagai komplikasi pada kelompok maupun anak baru lahir dan perempuan. Anemia pada remaja akan berdampak pada penurunan konsentrasi belajar, penurunan kesegaran jasmani, dan gangguan pertumbuhan sehingga tinggi badan dan berat badan tidak mencapai normal (Masthalina, 2015).

Dampak anemia pada remaja putri dan status gizi yang buruk memberikan kontribusi negatif bila hamil pada usia remaja ataupun saat dewasa yang dapat menyebabkan kelahiran bayi dengan berat badan lahir rendah, kesakitan bahkan kematian pada ibu dan bayi. Selain itu, anemia juga mempunyai dampak negatif terhadap perkembangan fisik dan kognitif remaja (WHO, 2008).

Berdasarkan Irawan, (2018) prevalensi anemia di Asia Tenggara dan Afrika mencapai $85 \%$, dengan wanita dan anak-anak sebagai penderita terbanyak. Dari data Kemenkes, (2013) terdapat 21,7\% penduduk Indonesia dengan kadar hemoglobin yang kurang dari batas normal dengan proporsi $20,6 \%$ di perkotaan dan $22,8 \%$ di pedesaan serta $26,4 \%$ penderita anemia berumur 5-14 tahun dan 18,4\% berumur 15-24 tahun. Sedangkan data lain menunjukan bahwa pada remaja usia 13-19 tahun di Jawa Barat prevalensi anemia mencapai $42,4 \%$ yang diperoleh dari beberapa faktor yaitu asupan energi, protein, zat besi, vitamin $\mathrm{C}$, kebiasaan minum teh dan kopi serta karena pola menstruasi (Megawati, 2016). Menurut Megabohari, (2011) Salah satu faktor pemicu anemia adalah kondisi siklus menstruasi yang tidak normal. Kehilangan darah yang sebenarnya apabila mengalami kadar menstruasi yang berlebihan lebih dari 3-4 hari, pembalut atau tampon selalu basah setiap jamnya dan sering menggantinya. Jika hal ini terjadi lebih 
JURNAL ILMU KESEHATAN BHAKTI HUSADA:

HEALTH SCIENCES JOURNAL, VOL. 11 NO. 01, JUNI 2020

DOI: $10.34305 /$ jikbh.v11i1.154

dari 3 hari, maka segera kunjungi dokter, dan apabila pada saat menstruasi terlihat pucat atau merasa ingin pingsan jangan tunggu sampai tiga hari. Kehilangan banyak darah saat menstruasi diduga dapat menyebabkan anemia (Nurani, 2013).

Anemia merupakan suatu keadaan dimana komponen di dalam darah yaitu hemoglobin dalam darah jumlahnya kurang dari kadar normal. Remaja putri memiliki risiko sepuluh kali lebih besar untuk menderita anemia dibandingkan dengan remaja putra. Hal ini dikarenakan remaja putri mengalami menstruasi setiap bulannya dan sedang dalam masa pertumbuhan sehingga membutuhkan asupan zat besi yang lebih banyak. Penentuan anemia juga dapat dilakukan dengan mengukur hematokrit (Ht) yang rata-rata setara dengan tiga kali kadar hemoglobin. Batas kadar hemoglobin remaja putri untuk mendiagnosis anemia yaitu apabila kadar hemoglobin kurang 12 gr/dl (Tarwoto et al., 2010).

Untuk penanganan anemia, pemerintah sudah mempunyai program puskesmas seperti program peningkatan gizi masyarakat, program kesehatan ibu dan anak, dan program penyuluhan kesehatan masyarakat. namun pencegahan anemia hanya ditujukan pada ibu hamil yang memiliki resiko paling tinggi mengalami anemia defisiensi besi.
Sementara itu kelompok perempuan yang beresiko mengalami anemia juga berasal dari kelompok remaja premenarche dan postmenarche. Untuk penanganan anemia pada kelompok premenarche dan postmenarche seharusnya ditangani oleh program Usaha Kesehatan Sekolah (UKS) bekerja sama dengan puskesmas dalam penjaringan dan pemeriksaan kesehatan berkala. Namun UKS belum pernah bekerja sama untuk skrining anemia pada siswi sekolah. Pemeriksaan hemoglobin untuk mengetahui anemia wajib dilakukan karena perempuan akan melahirkan generasi penerus bangsa yang seharusnya berkualitas dan sehat (Dharma \& Sudhana, 2013). Dari hasil studi pendahuluan yang dilakukan di Desa Ragawacana Kecamatan Kramatmulya Kabupaten Kuningan, didapat jumlah remaja perempuan usia 1016 tahun sebanyak 202 remaja, dan diambil 20 orang sebagai sampel untuk dilakukan wawancara. Dari hasil tersebut didapatkan 6 orang usia 10-13 tahun mengatakan belum mengalami menstruasi, sedangkan 14 orang usia 14-16 tahun mengatakan sudah mengalami menstruasi.

Hasil penelitian Dharma \& Sudhana, (2013) pada kelompok premenarche dengan rentang umur 10-12 tahun proporsi yang terjadi pada kelompok ini adalah $12 \%$ dengan kadar hemoglobin terendah 7,5gr/dl sampai tertinggi $16 \mathrm{gr} / \mathrm{dl}$, 
JURNAL ILMU KESEHATAN BHAKTI HUSADA:

HEALTH SCIENCES JOURNAL, VOL. 11 NO. 01, JUNI 2020

DOI: $10.34305 /$ jikbh.v11i1.154
Ciptaan disebarluaskan di bawah

Lisensi Creative Commons Atribusi-

NonKomersial-BerbagiSerupa 4.0 Internasional nilai rata-rata hemoglobin adalah 13,3 gr/dl. Sedangkan pada kelompok postmenarche dengan rentang usia sampel 13-16 tahun rata-rata hemoglobin pada kelompok ini adalah 14,5 gr/dl dengan kadar hemoglobin terendah 11,0 gr/dl dan tertinggi $16,6 \mathrm{gr} / \mathrm{dl}$.

Dari hasil penelitian Nugrahani, (2013) menunjukkan bahwa rata- rata kadar hemoglobin responden sebelum menstruasi adalah 11,88 gr/dl dan sesudah menstruasi turun menjadi 10,61 gr/dl. Berdasarkan rata-rata kadar hemoglobin responden maka disimpulkan bahwa terjadi penurunan kadar hemoglobin pada siswi ketika mengalami menstruasi. Sedangkan hasil penelitian Megawati, (2016) pola menstruasi dan kejadian anemia diperoleh bahwa sebanyak 29 orang $(90,6 \%)$ remaja putri dengan pola menstruasi berisiko mengalami kejadian anemia. Sedangkan remaja putri yang memiliki pola menstruasi tidak beresiko, sebanyak 4 orang $(44,4 \%)$ tidak mengalami kejadian anemia.

\section{METODOLOGI PENELITIAN}

\section{Jenis dan Rancangan Penelitian}

\section{Jenis Penelitian}

Jenis penelitian yang dilakukan penulis adalah penelitian analitik. Penelitian analitik adalah survei atau penelitian yang mencoba menggali bagaimana dan mengapa fenomena kesehatan itu terjadi. Kemudian melakukan analisis dinamika korelasi antara fenomena, baik antara faktor risiko dengan faktor efek, antar faktor risiko, atau antar faktor efek (Notoatmodjo, 2012).

\section{Rancangan Penelitian}

Rancangan penelitian ini adalah case control. Dalam penelitian ini yang termasuk ke dalam case yaitu kadar hemoglobin, sedangkan control adalah kelompok remaja premenarche dan postmenarche

\section{Populasi dan Teknik Pengambilan Sampel}

Populasi

Populasi yang ditentukan sebagai objek penelitian ini adalah remaja perempuan usia 10-16 tahun di Desa Ragawacana Kecamatan Kramatmulya Kabupaten Kuningan sebanyak 202 orang.

\section{Teknik Pengambilan Sampel}

Pada penelitian ini pengambilan sampel dilakukan dengan menggunakan teknik Accidental sampling dimana pengambilan sampel ini dilakukan dengan mengambil kasus atau responden yang kebetulan ada atau tersedia, yang berarti sampel diambil dari responden atau kasus yang kebetulan ada (Notoatmodjo, 2012).

\section{Variabel Penelitian}

Variabel Bebas

E-ISSN 2623-1204 P-ISSN 2252-9462 | 74 
JURNAL ILMU KESEHATAN BHAKTI HUSADA:

HEALTH SCIENCES JOURNAL, VOL. 11 NO. 01, JUNI 2020

DOI: $10.34305 /$ jikbh.v11i1.154

Variabel bebas dalam penelitian ini yaitu remaja premenarche dan postmenarche.

\section{Variabel Terikat}

Variabel terikat dalam penelitian ini adalah kadar hemoglobin pada remaja di Desa Ragawacana Kecamatan Kramatmulya Kabupaten Kuningan.

\section{Instrumen Pengumpulan Data}

Alat pengumpulan data yang digunakan penulis dalam penelitian ini adalah menggunakan lembar observasi dengan cara ukur checklist.

\section{Analisis Univariat}

Rata-rata (Mean)

Rata-rata atau mean adalah ukuran rata-rata yang merupakan hasil bagi dari jumlah semua nilai pengukuran dibagi oleh banyaknya pengukuran. Secara sederhana perhitungan nilai mean dapat dituliskan dengan rumus:

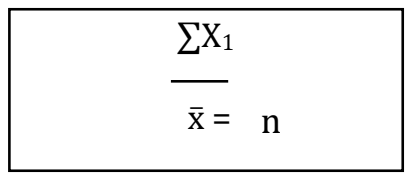

Keterangan:

$\mathrm{x}^{-}=$rata-rata data observasi

$\mathrm{n}=$ banyaknya data observasi

$\mathrm{X}_{1}=$ nilai data observasi

$\sum=$ jumlah

\section{Analisis Bivariat}

Sebelum dilakukan uji t-test independent dilakukan uji normalitas data dengan uji Shapiro-Wilk. Karena data

berdistribusi normal, dilakukan uji homogenitas atau varian dengan uji F-test. Dalam penelitian ini, kedua kelompok data mempunyai varian yang sama sehingga nilai uji t-test independent dibaca pada equal variance. Rumus manual uji homogenitas varian adalah sebagai berikut

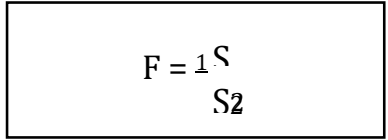

Keterangan:

$\mathrm{F}=$ Nilai $\mathrm{F}$ hitung

$\mathrm{S}^{2}=$ Nilai Varian 1 terbesar

$\mathrm{S}^{2}=$ Nilai varian $\quad$ 2terkecil

Data dinyatakan memiliki varian yang

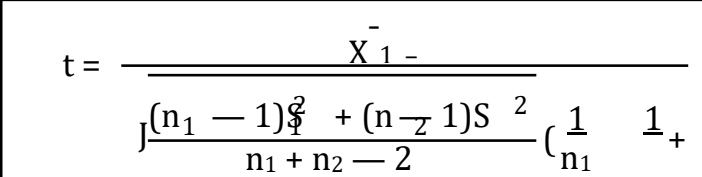

$$
\begin{aligned}
& \mathrm{t}=\frac{\mathrm{x}_{1}^{-}-\mathrm{X}_{2}}{\mathrm{~J}}
\end{aligned}
$$

sama (equal variance) bila F-Hitung < FTabel, dan sebaliknya, varian data dinyatakan tidak sama (unequal variance) bila F-Hitung > F-Tabel bentuk varian kedua kelompok data akan berpengaruh pada nilai standar error yang akhirnya akan membedakan rumus pengujiannya. Uji $t$ untuk varian yang sama (equal variance) menggunakan rumus manual E-ISSN 2623-1204 P-ISSN 2252-9462 |75 
JURNAL ILMU KESEHATAN BHAKTI HUSADA:

HEALTH SCIENCES JOURNAL, VOL. 11 NO. 01, JUNI 2020

DOI: $10.34305 /$ jikbh.v11i1.154

Polled Variance: Uji t untuk varian yang berbeda (unequal variance) menggunakan rumus manual Separated Variance dibawah ini:

Keterangan:

$\mathrm{X}^{-} 1$ = rata-rata data kelompok pertama

$\mathrm{X}^{-} 2$ = rata-rata kelompok kedua $\mathrm{S}^{2}=$

\section{HASIL DAN PEMBAHASAN}

\section{Hasil Penelitian}

Analisis Univariat

1. Gambaran Rata-rata Kadar Hemoglobin Remaja Premenarche dan Postmenarche di Desa Ragawacana Kecamatan

Kramatmulya Kabupaten Kuningan Tahun 2018.

Berikut ini merupakan tabel gambaran dan
Varians sampel pertama $S^{2}=$ Varians sampel kedua

$\mathrm{n}_{1}=$ banyaknya sampel pengukuran

kelompok pertama

$\mathrm{n}_{2}=$ banyaknya sampel pengukuran

kelompok kedua.

standar devisiensi rata- rata kadar hemoglobin remaja premenarche di Desa Ragawacana Kecamatan Kramatmulya Kabupaten Kuningan Tahun 2018, dapat dilihat dari tabel berikut ini:

Tabel 1 Gambaran Rata-rata Kadar Hemoglobin Remaja Premenarche dan Postmenarche di Desa Ragawacana Kramatmulya Kabupaten Kuningan Tahun 2018 .

\begin{tabular}{|l|c|c|l|l|}
\hline \multirow{2}{*}{ Remaja } & \multicolumn{3}{|l|}{ Kadar Hemoglobin } & \multirow{2}{*}{ N } \\
\cline { 2 - 4 } & Mean & Median & Min - Max & \\
\hline Premenarche & 12,9 & 12,5 & $10,6-16,0$ & 22 \\
\hline Postmenarche & 12,0 & 12,2 & $8,8-15,0$ & 20 \\
\hline Total & & 42 \\
\hline
\end{tabular}

Sumber : Penelitian 2018

Berdasarkan tabel 5.1 dapat diketahui bahwa dari 42 responden remaja premenarche dan postmenarche yang diobservasi, terdapat 22 remaja yang belum menstruasi (premenarche), berdasarkan pengukuran kadar hemoglobin rata-rata hemoglobin pada remaja premenarche adalah 12,8 gr/dl, dengan kadar hemoglobin terendah 10,6 gr/dl dan kadar hemoglobin tertinggi 16,0 gr/dl. Sedangkan dari 20 orang remaja postmenarche (yang sudah mengalami menstruasi), rata-rata kadar hemoglobinnya adalah 12,0 gr/dl, dengan 
JURNAL ILMU KESEHATAN BHAKTI HUSADA:

HEALTH SCIENCES JOURNAL, VOL. 11 NO. 01, JUNI 2020

DOI: $10.34305 /$ jikbh.v11i1.154

kadar hemoglobin terendah 8,8 gr/dl dan kadar hemoglobin tertinggi 15,0 gr/dl.

Analisis Bivariat

Perbandingan Rata-rata Kadar

Hemoglobin Remaja Premenarche dan

Postmenarche di Desa Ragawacana

Kecamatan Kramatmulya Kabupaten

Kuningan Tahun 2018.

Berikut ini merupakan tabel

perbandingan rata-rata kadar hemoglobin

\begin{tabular}{|l|l|l|l|l|}
\hline Variabel & Rerata & P Value & $\begin{array}{c}\text { Perbedaan rerata } \\
\text { (CI 95\%) }\end{array}$ & N \\
\hline Premenarche & $12,90,087$ & $0,88(-0,1240-$ & 22 \\
\cline { 1 - 2 } Postmenarche & 12,0 & $1,8986)$ & 20 \\
\hline Total & & 42 \\
\hline
\end{tabular}

Sumber : Penelitian 2018

Berdasarkan tabel 5.2 dapat diketahui bahwa rata-rata kadar hemoglobin remaja premenarche adalah $12,9 \mathrm{gr} / \mathrm{dl}$ dengan standar deviasi 1,7884 gr/dl. Sedangkan untuk remaja postmenarche rata-rata kadar hemoglobinnya adalah 12,0 gr/dl dengan standar deviasi 1,4478 gr/dl. Hasil uji statistik didapatkan nilai $\mathrm{p}=0,087$ berarti

\section{Pembahasan}

\section{Analisis Univariat}

Berdasarkan hasil penelitian yang didapat bahwa dari 42 responden remaja yang telah diobservasi terdapat 22 orang yang belum mengalami menstruasi dengan rata-rata kadar hemoglobin 12,9 gr/dl. Sedangkan pada remaja yang sudah remaja premenarche dan postmenarche di Desa Ragawacana Kecamatan Kramatmulya Kabupaten Kuningan Tahun 2018, dapat dilihat dari tabel berikut ini:

Tabel 5.2 Distribusi Perbandingan Rata-rata Kadar Hemoglobin pada Remaja Premenarche dan Postmenarche di Desa Ragawacana Kecamatan Kramatmulya Kabupaten Kuningan Tahun 2018. 
JURNAL ILMU KESEHATAN BHAKTI HUSADA:

HEALTH SCIENCES JOURNAL, VOL. 11 NO. 01, JUNI 2020

DOI: $10.34305 /$ jikbh.v11i1.154
Ciptaan disebarluaskan di bawah

Lisensi Creative Commons Atribusi-

NonKomersial-BerbagiSerupa 4.0 Internasional memasuki usia antara 10-16 tahun. Pada masa pubertas mereka mengalami perubahan- perubahan di dalam tubuh yang memungkinkan untuk bereproduksi. Anak perempuan lebih cepat dewasa dibandingkan dengan anak laki-laki, organ reproduksinya mulai berfungsi, salah satu ciri masa pubertas pada perempuan adalah terjadinya menstruasi pertama (Proverawati \& Misaroh, 2009).

Remaja perempuan yang mengalami menstruasi memiliki kecenderungan defisiensi zat besi sebanyak $5 \%$ sampai dengan $10 \%$ sehingga remaja perempuan yang mengalami menstruasi rentan terhadap terjadinya penurunan kadar hemoglobin atau anemia. Berdasarkan hasil penelitian Megawati, (2016) pola menstruasi dan kejadian anemia diperoleh bahwa sebanyak 29 orang $(90,6 \%)$ remaja putri dengan pola menstruasi berisiko mengalami kejadian anemia. Sedangkan remaja putri yang memiliki pola menstruasi tidak beresiko, sebanyak 4 orang $(44,4 \%)$ tidak mengalami kejadian anemia.

Selama menstruasi, remaja perempuan mengalami pengeluaran atau kehilangan darah yang banyak. Seiring dengan pengeluaran atau kehilangan darah, maka zat besi pada darah juga ikut hilang sehingga menyebabkan defisiensi zat besi. Salah satu unsur penting untuk proses pembentukan sel darah merah adalah zat besi. Anemia yang disebabkan oleh rendahnya kadar zat besi merupakan defisiensi besi. Wanita lebih mungkin dibandingkan pria untuk memiliki anemia kekurangan zat besi karena kehilangan darah setiap bulan melalui menstruasi normal. Penyebab defisiensi besi adalah pendarahan berlebih saat menstruasi, kurangnya asupan makanan, dan gangguan penyerapan. Secara umum, wanita memiliki simpanan zat besi lebih sedikit daripada pria karena mereka kehilangan lebih banyak melalui menstruasi (Proverawati, 2011).

\section{Analisis Bivariat}

Perbandingan Rata-rata Kadar Hemoglobin Remaja Premenarche dan Postmenarche di Desa Ragawacana Kecamatan Kramatmulya Kabupaten Kuningan Tahun 2018.

Berdasarkan hasil penelitian yang didapat 22 remaja premenarche dengan rata-rata kadar hemoglobin 12,9 gr/dl. Sedangkan dari 20 orang remaja postmenarche rata-rata kadar hemoglobinnya adalah 12,0 gr/dl. Hasil uji statistik didapatkan nilai $\mathrm{p}=0,087$ berarti pada alpha 5\% tidak ada perbedaan yang signifikan, rata-rata kadar hemoglobin antara remaja yang belum menstruasi dan yang sudah menstruasi dengan nilai CI 
JURNAL ILMU KESEHATAN BHAKTI HUSADA:

HEALTH SCIENCES JOURNAL, VOL. 11 NO. 01, JUNI 2020

DOI: $10.34305 /$ jikbh.v11i1.154
Ciptaan disebarluaskan di bawah

Lisensi Creative Commons Atribusi-

NonKomersial-BerbagiSerupa 4.0 Internasional
$95 \% 0,88(-0,1240-1,8986)$. Hal ini tidak sesuai dengan hasil penelitian Dharma \& Sudhana, (2013) pada kelompok premenarche dengan rentang umur 10-12 tahun proporsi yang terjadi pada kelompok ini adalah 12\% dengan kadar hemoglobin terendah 7,5gr/dl sampai tertinggi $16 \mathrm{gr} / \mathrm{dl}$, nilai rata-rata hemoglobin adalah 13,3 gr/dl. Sedangkan pada kelompok postmenarche dengan rentang usia sampel 13-16 tahun rata-rata hemoglobin pada kelompok ini adalah 14,5 gr/dl dengan kadar hemoglobin terendah 11,0 gr/dl dan tertinggi 16,6 gr/dl, bahwa ada perbedaan yang signifikan pada kadar hemoglobin premenarche dan postmenarche. Hal ini disebabkan oleh adanya perbedaan ras, suku, adat antar daerah, dan faktor nutrisi yang dikonsumsi oleh remaja, serta karena jumlah sampel yang didapat tidak sesuai dengan target peneliti, yaitu hanya mendapatkan 42 responden, dari usia 1016 tahun yang belum mengalami menstruasi (premenarche) dan yang sudah menstruasi (postmenarche). Artinya sampel tersebut tidak dapat mewakili jumlah dari populasi remaja yang ada di Desa Ragawacana Kecamatan Kramatmulya Kabupaten Kuningan.

Berdasarkan dari hasil penelitian Prastika, (2011) diperoleh hasil $\mathrm{r}$ hitung $=$ 0,624 dan $\mathrm{p}=0,000(\mathrm{p}<0,05)$, terdapat hubungan antara siklus menstruasi, artinya semakin lama menstruasi maka akan semakin rendah kadar hemoglobin. Sehingga remaja yang sudah mengalami menstruasi akan lebih rentan terjadi anemia, karena kehilangan darah saat menstruasi berarti mengeluarkan zat besi yang ada dalam darah dan dapat menyebabkan terjadinya anemia. Lain halnya dengan remaja yang belum mengalami menstruasi mereka dapat terkena anemia karena disebabkan oleh kekurangan mikronutrien yaitu zat besi.

Penyebab paling banyak dari anemia defisiensi besi adalah kurangnya asupan salah satu mikronutrien penting yaitu zat besi. Anemia defisiensi zat besi masih merupakan penyakit dengan prevalensi tinggi. Sehingga pemenuhan kebutuhan zat besi ini diperlukan untuk mencegah atau menanggulangi anemia, hal ini sesuai dengan teori yang disampaikan oleh Almatsier, (2010) yang mengatakan bahwa pemberian tablet tambah darah merupakan salah satu penanganan yang dilakukan untuk menanggulangi anemia pada remaja. Untuk penanganan anemia pada kelompok premenarche dan postmenarche seharusnya ditangani oleh program Usaha Kesehatan Sekolah (UKS) bekerja sama dengan puskesmas dalam penjaringan dan pemeriksaan kesehatan berkala. Namun UKS belum pernah bekerja sama untuk skrining anemia pada 
JURNAL ILMU KESEHATAN BHAKTI HUSADA:

HEALTH SCIENCES JOURNAL, VOL. 11 NO. 01, JUNI 2020

DOI: $10.34305 /$ jikbh.v11i1.154
Ciptaan disebarluaskan di bawah Lisensi Creative Commons Atribusi-

NonKomersial-BerbagiSerupa 4.0 Internasional. siswi sekolah. Pemeriksaan hemoglobin untuk mengetahui anemia wajib dilakukan karena perempuan akan melahirkan generasi penerus bangsa yang seharusnya berkualitas dan sehat (Dharma \& Sudhana, 2013).

Berdasarkan uraian tersebut peneliti berpendapat bahwa salah satu faktor penyebab terjadinya anemia pada wanita adalah kehilangan darah pada saat menstruasi dan kurangnya asupan mikronutrien yaitu zat besi. Kadar hemoglobin yang didapat pada remaja usia 10-16 tahun remaja yang mengalami anemia rata-rata disebabkan karena kurangnya asupan salah satu mikronutrien penting yaitu zat besi dan pola menstruasi yang beresiko, sehingga sangat berpengaruh terhadap penurunan kadar hemoglobin. Dampak anemia pada remaja putri dan status gizi yang buruk memberikan kontribusi negatif bila hamil pada usia remaja ataupun saat dewasa yang dapat menyebabkan kelahiran bayi dengan berat badan lahir rendah, kesakitan bahkan kematian pada ibu dan bayi. Selain

\section{Saran}

1. Bagi remaja

Berdasarkan temuan hasil penelitian maka diharapkan untuk para remaja dapat mengerti dan memahami pentingnya asupan nutrisi serta pengetahuan tentang kesehatan itu, anemia juga mempunyai dampak negatif terhadap perkembangan fisik dan kognitif remaja (WHO, 2008).

\section{KESIMPULAN DAN SARAN}

\section{Kesimpulan}

Berdasarkan hasil penelitian dan pembahasan mengenai perbandingan kadar hemoglobin pada Remaja Premenarche dan Postmenarche di Desa Ragawacana Kecamatan Kramatmulya Kabupaten Kuningan Tahun 2018, maka penulis membuat kesimpulan sebagai berikut:

1. Remaja premenarche rata-rata kadar hemoglobin adalah 12,8 gr/dl, dengan kadar hemoglobin terendah 10,6 gr/dl dan kadar hemoglobin tertinggi 16,0 gr/dl.

2. Remaja postmenarche rata-rata kadar hemoglobin adalah 12,0 gr/dl, dengan kadar hemoglobin terendah $8,8 \mathrm{gr} / \mathrm{dl}$ dan kadar hemoglobin tertinggi 15,0 gr/dl

3. Tidak terdapat Perbandingan Kadar Hemoglobin pada Remaja

Premenarche dan Postmenarche reproduksi khususnya pada pengaruh menstruasi terhadap kadar hemoglobin.

2. Bagi Desa Ragawacana sebagai lokasi Penelitian

Diharapkan hasil penelitian ini bisa membantu Desa Ragawacana agar dapat bekerja sama dengan Puskesmas

E-ISSN 2623-1204 P-ISSN 2252-9462 | 80 
JURNAL ILMU KESEHATAN BHAKTI HUSADA:

HEALTH SCIENCES JOURNAL, VOL. 11 NO. 01, JUNI 2020

DOI: $10.34305 /$ jikbh.v11i1.154

atau Tenaga Kesehatan lainnya untuk memberikan pendidikan kesehatan tentang gizi seimbang remaja, kesehatan reproduksi, serta dapat mendukung program pemerintah yang sudah ada yaitu pemberian asam folat dan tablet tambah darah.

\section{DAFTAR PUSTAKA}

Almatsier, S. (2010). Prinsip dasar ilmu gizi, PT. Gramedia Pustaka Utama, Jakarta.

Dharma, I. P. R. W., \& Sudhana, I. W. (2013). Gambaran Anemia Pada Kelompok Perempuan Di Wilayah Kerja Puskesmas Tembuku I Kabupaten Bangli Tahun 2013. EJurnal Medika Udayana.

Irawan, D. (2018). Kenali Gejala Anemia pada Anak. https://lifestyle.bisnis.com/read/20180 722/106/819321/kenali-gejalaanemia-pada-anak

Kemenkes, R. I. (2013). Riset kesehatan dasar (Riskesdas) 2013. Kemenkes RI. Jakarta.

Masthalina, H. (2015). Pola Konsumsi (faktor inhibitor dan enhancer fe) terhadap Status Anemia Remaja Putri. KEMAS: Jurnal Kesehatan Masyarakat, 11(1), 80-86.

Megabohari. (2011). Anemia Saat Menstruasi. http://megabohari@yahoo.com

Megawati, M. (2016). Hubungan Pola

Makan dan Pola Menstruasi Remaja

Putri Ma Athoriyah Kecamatan

Cikatomas Kabupaten Tasikmalaya

Tahun 2016. Jurnal Kesehatan

Komunitas IndonesiaVol. 12 No 2 September 2016.

Notoatmodjo, S. (2012). Metodologi penelitian kesehatan (Cetakan VI). In PT. Rineka Cipta.

Nugrahani, I. (2013). Perbedaan Kadar Hemoglobin Sebelum dan Sesudah Menstruasi Pada Mahasiswa D III Keperawatan Universitas Muhamadiyah Surakarta. http://eprints.ums.ac.id/28870/20/NA SKAH_PUBLIKASI.pdf

Nurani, N. A. (2013). Menstruasi Tidak Normal Waspada Anemia. https://lifestyle.okezone.com/read/201 3/03/27/482/782461/menstruasi-tidaknormal-waspada-anemia

Prastika, D. A. (2011). Hubungan Lama Menstruasi Terhadap Kadar Hemoglobin Pada Remaja Siswi SMAN 1 Wonosari. Karya Tulis Ilmiah, Universitas Sebelas Maret). Surakarta.

Proverawati, A. (2011). Anemia dan Anemia kehamilan. Yogyakarta: Nuha Medika, 136-137.

Proverawati, A., \& Misaroh, S. (2009). E-ISSN 2623-1204 P-ISSN 2252-9462 | 81 
JURNAL ILMU KESEHATAN BHAKTI HUSADA:

HEALTH SCIENCES JOURNAL, VOL. 11 NO. 01, JUNI 2020

DOI: $10.34305 /$ jikbh.v11i1.154

Menarche menstruasi pertama penuh

makna. Yogyakarta: Nuha Medika, 144.

Tarwoto, A. R., Nuraeni, A., Miradwiyana, B., \& Nurbayani, S. (2010). Aminah S. dkk. 2010. Kesehatan Remaja Problem Dan Solusinya. Jakarta: Salemba Medika, 25-28.

WHO, C. D. C. (2008). Worldwide prevalence of anaemia 1993-2005. WHO Global Database on Anaemia. 
JURNAL ILMU KESEHATAN BHAKTI HUSADA:

HEALTH SCIENCES JOURNAL, VOL. 11 NO. 01, JUNI 2020

DOI: $10.34305 /$ jikbh.v11i1.154
Ciptaan disebarluaskan di bawah Lisensi Creative Commons Atribusi-

NonKomersial-BerbagiSerupa 4.0

(c) (1) (2) 